\title{
Irracjonalność legalizacji związków homoseksualnych wobec jedynej i niepowtarzalnej wartości i roli małżeństwa i rodziny
}

Powszechne doświadczenie poszczególnych osób i społeczności na przestrzeni wieków poparte autentyczną naukową argumentacją różnej proweniencji autorytetów dowodzi, iż ci, którzy pełnili kiedykolwiek rolę rodzica, a która jest najdonioślejszą z misji, ról i zadań człowieka względem ludzkości, cieszyli się i niezmiennie cieszą się powszechnym uznaniem i wdzięcznością ze strony poszczególnych ludzi i społeczności. Dlatego muszą zdumiewać, następnie dziwić, a wreszcie budzić dezaprobatę akty legalizowania przez niektóre parlamenty tego rodzaju związków, które stoją w jaskrawej sprzeczności z instytucją małżeństwa i rodziny.

To prawda, że istnieje, jak stwierdza Katechizm Kościoła Katolickiego, pewna liczba mężczyzn i kobiet, którzy ewidentnie przejawiają skłonności homoseksualne ${ }^{1}$, ale też fakt ten nie upoważnia nikogo, nawet najwyższych gremiów prawodawczych do tego, by tego rodzaju skłonności miały prawo zyskać, w przypadku nieformalnych związków homoseksualnych, uznanie i usankcjonowanie w formie aktu ich legalizacji. W tej kwestii Magisterium Kościoła zajmuje jednoznacznie zdecydowane stanowisko, stwierdzając, że: ,akty homoseksualizmu z samej swojej wewnętrznej natury są nieuporządkowane. Są one sprzeczne z prawem naturalnym, wykluczają bowiem z aktu płciowego dar życia" ", co więcej - ponieważ nie wynikają one z prawdziwej komplementarności uczuciowej i płciowej ${ }^{3}$, i dlatego, jak się podkreśla: „W żadnym wypadku nie będą mogły zostać zaaprobowane"4. Innymi słowy, legalizacja tego rodzaju związków ze strony prawodawcy świeckiego, jako że są odejściem od czy

\footnotetext{
${ }^{1}$ Por. Katechizm Kościoła Katolickiego (dalej: KKK), Poznań 1994, 2358.

${ }^{2}$ Tamże, 2357.

${ }^{3}$ Por. tamże.

${ }^{4}$ Tamże.
} 
pogwałceniem prawa naturalnego ${ }^{5}$, nie może zyskać poparcia i uznania ze strony Kościoła katolickiego.

Opierając analizy i refleksje na nauce Urzędu Nauczycielskiego Kościoła ${ }^{6}$, zamierza się uwydatnić i przybliżyć racjonalność użytych argumentów przez Magisterium Kościoła na rzecz słusznych rozwiązań nauki oraz określeń i ustaleń prawnych, mających na celu promocję małżeństwa i rodziny jako jedynych form zdrowej gwarancji rozwoju poszczególnych osób oraz społeczności ludzkich.

\section{Wprowadzenie w problematykę stanowiska Kongregacji Nauki Wiary}

Nie podlega kwestii fakt, co może pobrzmiewać truizmem w rozważaniu nad obecnym problemem, że człowiek w swej strukturze psychofizycznej istotnie różni się od świata innych istot stworzonych. Elementem radykalnie odróżniającym go od nich, owszem stawiającym go ponad nimi, jest fakt - choć nie przez wszystkich dostrzegany i uznawany - że człowiek został stworzony na obraz i podobieństwo swego Stwórcy ${ }^{7}$. Dzięki temu, jak naucza Jan Paweł II w encyklice Evangelium vitae: „Człowiek jest powołany do pełni życia, przekracza znacznie wymiary jego ziemskiego bytowania, ponieważ polega na uczestnictwie w życiu samego Boga"8. Dlatego może zdumiewać fakt, iż fascynacja osiągnięciami, jakimi szczyci się ludzki geniusz, w pewnych przypadkach oddala go, a nawet odrywa od przestrzeni sacrum, co nie pozwala na przyjęcie i uznanie pierwiastka etycznego i moralnego, w gruncie rzeczy nie tylko niesprzecznego z postulatem życia, lecz wręcz domagającego się racjonalności, jako zasadniczego dla niego tła i motywu dla osobistego rozwoju. Dochodzi wręcz - jak coraz częściej niepokojąco się konstatuje - do rozziewu między ścisłym związkiem między wiedzą a mądrością ${ }^{9}$ który to związek widoczny był nie tylko u starożytnych Greków.

Jeśli zatem - jak to podkreśla wielu myślicieli - jesteśmy stworzeni na obraz Boga, to $\mathrm{z}$ naukowego punktu widzenia nie ma nic zdumiewającego $\mathrm{w}$ fakcie, że potrafimy rozumieć świat, do którego należymy. Na potwierdzenie swej obserwacji myśliciele ci przytaczają słynną wypowiedź Keplera, wedle której uprawiając naukę, jedynie „idziemy za Bożą myślą"10.

W szeroko zakrojonej refleksji nad relacją wolności do prawa moralnego, którego nie sposób eliminować z życia bez uszczerbku dla jego racjonalności, Jan Paweł II

\footnotetext{
${ }^{5}$ Por. KKK 2070-2073, 1901, 1952, 2036.

${ }^{6}$ Uwagi i refleksje dotyczą III części dokumentu Kongregacji Nauki Wiary, Uwagi dotyczace projektów legalizacji związków między osobami homoseksualnymi, Libreria Editrice Vaticana 2003.

${ }^{7}$ Por. Rdz 1, 27.

${ }^{8}$ Jan Paweł II, Enc. Evangelium vitae, 2.

${ }^{9}$ Por. G. Marcel, Mądrość i poczucie sacrum, tłum. K. Chodacki, P. Chołda, Kraków 2011, s. 64-65.

${ }^{10}$ D. Aleksander, R. S. White, Nauka blisko wiary - nowe wyzwania etyczne, Warszawa 2006, s. 90.
} 
stwierdza, iż przyjmując prawo moralne, ludzka wolność naprawdę i w pełni się urzeczywistnia ${ }^{11}$. Oceniając krytycznie tzw. argumenty biologistyczne lub naturalistyczne, papież sformułował w odnośnej kwestii następujące, o doniosłym znaczeniu stwierdzenie: „Wolność, która uważa się za absolutną, prowadzi do traktowania człowieka jako surowca pozbawionego znaczeń i wartości moralnych, dopóki ona nie ukształtuje go według własnego zamysłu" ${ }^{\prime 2}$. W ten oto sposób - wnosi Jan Paweł II - „natura ludzka i ciało jawią się jako wstępne dane czy przestanki dla wyborów dokonywanych przez wolność, materialnie niezbędne, ale zewnętrzne wobec osoby, wobec podmiotu i ludzkiego działania"13. W tym kontekście - konkluduje Jan Paweł II - „napięcie między wolnością a tak zredukowaną naturą oznacza rozłam w samym człowieku" ${ }^{14}$. Czy wobec tego można jeszcze mówić, jeśli nie zdezawuuje się tego rodzaju poglądów i tendencji, z gruntu antyhumanistycznych, o perspektywach integralnego rozwoju tak w wymiarze jednostkowym, jak i społecznym?

\section{Konieczność respektu dla zasad etycznych w życiu i postępowaniu indywidualnym i społecznym}

W trzeciej części Uwag Kongregacji Nauki Wiary, zatytułowanej Argumenty racjonalne przeciwko legalizacji prawnej zwiąków homoseksualnych ${ }^{15}$, w pierwszym akapicie pod nr 6. czytamy: „Zrozumienie racji, powodujących konieczność przeciwstawienia się w ten sposób instancjom starającym się o zalegalizowanie związków homoseksualnych, wymaga kilku specyficznych uwag etycznych, różnych w swej naturze" 16 .

\section{Argument prawego rozumu (recta ratio)}

Podejmując istotną na gruncie epistemologii kwestię argumentu prawego rozumu (recta ratio $)^{17}$, Jan Paweł II w encyklice Evangelium vitae zapisał: ,Zadanie prawa cywilnego jest niewątpliwie bardziej ograniczone niż prawa moralnego"18. Niemniej, jak stwierdza Kongregacja Nauki Wiary, powołując się na słowa papieża: ,„prawo cywilne nie może wchodzić w konflikt z prawym rozumem (recta ratio), bez utraty tym samym mocy wiążącej dla sumienia"19. To zaś oznacza, wyjaśnia się dalej, że:

${ }^{11}$ Por. Jan Paweł II, Enc. Veritatis splendor, 35.

12 Tamże, 48.

13 Tamże.

${ }^{14}$ Tamże.

${ }^{15}$ Kongregacja Nauki Wiary, Uwagi dotyczace projektów..., s. 12.

16 Tamże.

${ }^{17}$ Wyrażenie recta ratio (ang. right reason) wywodzące się z gr. orthos logos thumaczy się najczęściej jako „słuszny rozum”, „słuszny osąd”. Por. V. J. Bourke, Historia etyki, thum. A. Białek, Toruń 1994, s. 88.

${ }^{18}$ Jan Paweł II, Enc. Evangelium vitae, 25.

${ }^{19}$ Por. Kongregacja Nauki Wiary, Uwagi dotyczace projektów..., s. 12. 
„Każde prawo ustanowione przez ludzi ma rację bytu jako prawo na tyle, na ile jest zgodne z prawem moralnym, uznawanym przez prawy rozum (recta ratio), i na ile respektuje w szczególności prawa każdej osoby"20. Dla lepszego rozumienia ostatniego stwierdzenia niech posłuży następująca teza i wniosek Bourke'a, wedle którego wszystko, co się dzieje, posiada swoją rację (logos). „Gdyby ludzie byli mądrzy - nie bez przekory zauważa - byliby w stanie uchwycić wszystkie te «racje» i nie wahaliby się przed dostosowaniem swych wewnętrznych, świadomych postaw i sądów do wymagań rozumu” ${ }^{21}$. „To samo można wyrazić, mówiąc - zauważa dalej - że prawo (nomos) jest po prostu uogólnionym nakazem rozumu"22, co znakomicie oddaje następująca obserwacja św. Tomasza z Akwinu, wedle której: „Właściwością rozumu jest porządkowanie"23. Ideę tę jeszcze wyraźniej potwierdza i wyraża słynna definicja prawa Akwinaty: „Lex est quaedam rationis ordinatio ad bonum commune, ab eo qui curam communitatis habet promulgata", do której odwołał się w swojej refleksji na temat współczesnej demokracji Jan Paweł II ${ }^{24}$. Powrót do korzeni współczesnej Europy, której kultura została głęboko osadzona w filozofii greckiej, w kulturze judeochrześcijańskiej i w prawie rzymskim, domaga się wierności zasadom, z których wyrosła ${ }^{25}$, o co w przejmujących słowach apeluje do współczesnych Jan Paweł II, pod znamiennym tytułem: „Powrót do Europy”26. Jeśli zaś idzie o prawo rzymskie, to stwierdza się, iż żaden z ludów starożytnych nie wniósł takiego i w takim stopniu wkładu do ogólnego rozwoju kulturowego ludzkości, jak to uczynili Rzymianie ${ }^{27}$, a to - jak się wydaje - zobowiązuje.

Powracając do wątku prawego rozumu (recta ratio), do - nazwijmy to: imperatywu ratio, racjonalnego myślenia - podkreślić i wyeksponować trzeba następującą konstatację Kongregacji Nauki Wiary:

Ustawodawstwa przychylne związkom homoseksualnym są sprzeczne z prawym rozumem, ponieważ udzielają gwarancji prawnych, analogicznych do tych, jakie przysługują instytucji małżeństwa, związkom między dwoma osobami tej samej płci ${ }^{28}$.

Rodzi się w związku z tym pytanie: czy takie ustawodawstwa nie widzą, czy nie chcą widzieć sprzeczności między czci godną instytucją małżeństwa, której znaczenie i rola jest nie do przecenienia dla życia, zarówno w wymiarze jednostkowym, rodzinnym i społecznym w porównaniu ze związkami, które roszczą sobie pretensje do zyskania pozycji równej małżeństwu? Kościół zdecydowanie sprzeciwia się tego rodzaju mentalności, tym bardziej tego rodzaju praktykom, oświadczając,

${ }^{20}$ Tamże, s. $12-13$.

${ }^{21}$ V. J. Bourke, Historia etyki, s. 91.

${ }^{22}$ Tamże.

${ }^{23}$ Tamże.

${ }^{24}$ Por. Jan Paweł II, Pamięć i tożsamość, Kraków 2005, s. 139.

${ }^{25}$ Por. D. Karłowicz, Sokrates i inni święci, Warszawa 2005, s. 13-67.

${ }^{26}$ Jan Paweł II, Pamięć i tożsamość, s. 141-150.

${ }^{27}$ Por. W. Wołodkiewicz, M. Zabłocka, Prawo rzymskie. Instytucje, Warszawa 1996, s. 27.

${ }^{28}$ Kongregacja Nauki Wiary, Uwagi dotyczace projektów..., 6, s. 13. 
że: „państwo nie może zalegalizować takich związków bez uchybienia swemu obowiązkowi promowania i ochrony zasadniczej instytucji dla dobra wspólnego, jaką jest małżeństwo"29.

Wypada zauważyć, a to odnosi się w pierwszym rzędzie do odpowiedzialnych za życie społeczne, zwłaszcza stanowiących prawo, z jak niemal dramatycznym apelem zwraca się Jan Paweł II w słowach: „stanowczo ponawiam mój apel do wszystkich polityków, aby nie wprowadzali ustaw, które nie uznają godności osoby i tym samym zagrażają samym korzeniom społecznego współżycia”30 „Zalegalizowanie związków homoseksualnych - konkluduje Kongregacja Nauki Wiary - powodowałoby zatem przysłonięcie niektórych fundamentalnych wartości moralnych i dewaluację instytucji małżeństwa" ${ }^{31}$. Niepodobna wręcz przypuszczać, nawet hipotetycznie, iż taka idea mogłaby przyświecać jakiemukolwiek ciału ustawodawczemu.

Argumenty z porządku biologicznego i antropologicznego

przeciw aktom legalizacji związków homoseksualnych

Racjonalne przesłanki wynikające z prawego rozumu (recta ratio) na rzecz wyłącznej promocji małżeństwa i rodziny stoją $\mathrm{w}$ radykalnie $\mathrm{w}$ jaskrawej sprzeczności z pozytywnymi aktami ustawodawczymi na rzecz promocji związków homoseksualnych. Nikt nie może zaprzeczyć, że naturalny porządek świata, zbudowany wedle stałych praw natury, konstytuuje się i legitymizuje pierwotnymi i niezbywalnymi instytucjami, jakimi są małżeństwo i oparta na nim rodzina ${ }^{32}$. Nie ma żadnych racjonalnych podstaw, by w tej materii tworzyć alternatywne teorie, stwarzając zachęty do eksperymentów, które nie mają racjonalnych podstaw do ich wprowadzania w życie, tym bardziej by im nadawać charakter statusu instytucjonalnego. W związku z tym oświadczenie Kongregacji Nauki Wiary jest jednoznaczne: „W związkach homoseksualnych brakuje całkowicie elementów biologicznych $\mathrm{i}$ antropologicznych małżeństwa i rodziny, które mogłyby być racjonalną podstawą dla zalegalizowania prawnego takich związków"33. Dlatego zbędne są - należy z całą mocą podkreślić - jakiekolwiek próby teoretycznych spekulacji, zwłaszcza że nie ma żadnych naukowych przesłanek na rzecz alternatywnych hybrydalnych instytucji, które by miały jakieś szanse, choćby efemeryczne, powodzenia. Stąd konkluzja Kongregacji Nauki Wiary jest jasna i jednoznaczna: „Nie są one w stanie zapewnić odpowiednio prokreacji i trwania rodzaju ludzkiego"34.

\footnotetext{
${ }^{29}$ Tamże.

${ }^{30}$ Jan Paweł II, Enc. Evangelium vitae, 90.

${ }^{31}$ Kongregacja Nauki Wiary, Uwagi dotyczace projektów..., 6, s. 14.

${ }^{32}$ Por. tamże, 4, s. 7; Z. Grocholewski, La legge naturalne nella dottrina della Chiesa, red.

L. Cirillo, Roma 2008, s. 50.

${ }^{33}$ Kongregacja Nauki Wiary, Uwagi dotyczace projektów..., 7, s. 14.

${ }^{34}$ Tamże, 7, s. 14-15.
} 
Jednoznaczne stanowisko Kościoła wyrażone wyżej przez Kongregację Nauki Wiary nie dopuszcza także ewentualnego sięgania przez związki homoseksualne po odkrycia w dziedzinie sztucznego zapłodnienia. Poza tym - jak podkreśla dokument - tego rodzaju manipulacje są poważnym uchybieniem szacunkowi, jaki należy się godności ludzkiej ${ }^{35}$. Co więcej, szacunek należny godności ludzkiej byłby tym bardziej wystawiony na zniewagę, owszem stanowiłby pośrednią aprobatę dla związków homoseksualnych, gdyby stwarzał im możliwość korzystania z efektów sztucznego zapłodnienia. By w końcu nie zostawiać cienia wątpliwości, dokument stwierdza wprost:

W związkach homoseksualnych jest też całkowicie nieobecny wymiar małżeński, który stanowi formę ludzką i uporządkowaną relacji płciowych. Są one rzeczywiście ludzkie tylko wtedy i tylko na tyle - podkreśla się - na ile wyrażają i umacniają wzajemne wsparcie płci w małżeństwie i pozostają otwarte na przekazywanie życia ${ }^{36}$.

Przekazywanie życia oraz wychowanie potomstwa, przypomina sobór watykański $\mathrm{II}^{37}$, występuje w ścisłym związku z wychowaniem potomstwa. Jak ważne i doniosłe to zadanie, które przede wszystkim spoczywa na tych, którzy przekazali nowe życie, świadczy fakt, że sobór poświęcił tej priorytetowej sprawie odrębny dokument - deklarację o wychowaniu chrześcijańskim ${ }^{38}$.

Legalizacja związków homoseksualnych pociąga za sobą, co ma miejsce w wielu przypadkach, koncesję władzy publicznej na rzecz przyznawania parom homoseksualnym prawa do adopcji. W sprawie tej stanowisko Kongregacji jest równie jednoznaczne, co stanowcze, które wyraża następująco:

Włączenie dzieci do związków homoseksualnych na drodze adopcji oznacza w rzeczywistości dokonanie przemocy na tych dzieciach w tym sensie, że wykorzystuje się ich bezbronność dla włączenia ich w środowisko, które nie sprzyja ich pełnemu rozwojowi ludzkiemu ${ }^{39}$.

Na specjalne podkreślenie, w rzeczonej kwestii, zasługuje tu następująca uwaga Kongregacji: akt adopcji ma znamiona przemocy w stosunku do dzieci, które są bezbronne tak wobec władzy, która zezwala na adopcję, jak i ze strony adoptujących, którzy nie są zdolni do wychowania dziecka zgodnie z jego ludzkimi potrzebami.

Oczywiście takie postępowanie - zwraca uwagę Kongregacja - byłoby poważnie niemoralne i pozostawałoby w jawnej sprzeczności z zasadą uznaną także przez Konwencję międzynarodową

${ }^{35}$ Szerzej na ten temat: Kongregacja Nauki Wiary, Instr. Donum vitae (22 II 1987).

${ }^{36}$ Kongregacja Nauki Wiary, Uwagi dotyczace projektów..., 7, s. 15. Por. Sobór watykański II, Konst. Gaudium et spes, 49; Jan Paweł II, Adh. Familiaris consortio, 28; Jan Paweł II, List do rodzin, 9; Karta Praw Rodziny, art. 1. c; Declaratio de quibusdam questionibus ad sexualem ethicam spectantibis, [w:] Congregatio pro Doctrina Fidei, Documenta inde a Consilio Vaticano Secundo expleto edita (1966-2005), Città del Vaticano 2006, s. 114.

${ }^{37}$ Por. Sobór watykański II, Konst. Gaudium et spes, 50.

${ }^{38}$ Sobór watykański II, Dekl. Gravissimum educationis, 3. Por. Kodeks prawa kanonicznego (dalej: KPK), Poznań 1983, kan. 1136.

${ }^{39}$ Kongregacja Nauki Wiary, Uwagi dotyczace projektów..., 7, s. 15-16. 
ONZ o prawach dzieci, według której najważniejszą wartością, którą trzeba chronić, jest w każdym wypadku dobro dziecka, będącego istotą słabszą i bezbronną ${ }^{40}$.

Argumenty przeciwne legalizacji prawnej związków

homoseksualnych dla zachowania porządku społecznego

Najważniejszym z punktu widzenia respektu dla wartości egzystencjalnej poszczególnych jednostek, a w konsekwencji dla określonych społeczności, jak stwierdza Kongregacja Nauki Wiary, jest małżeństwo i wywodząca się zeń oraz opierająca na niej swój byt rodzina ${ }^{41}$. Dlatego nie wolno zapominać, co nie zawsze sobie uświadamiano lub tego nie doceniano, że zaistniała na gruncie małżeństwa rodzina nie pomniejsza $\mathrm{w}$ dalszym istnieniu będącego u jej podstaw związku małżeńskiego. Powstała na bazie małżeństwa rodzina potwierdza i umacnia znaczenie struktury małżeństwa, co więcej, stwarza dzięki potomstwu nowe, żywotne impulsy dla jej dalszego prawidłowego rozwoju w perspektywie realizacji jej doniosłych zadań, jakimi są rodzenie i wychowanie potomstwa. Natomiast, jak stwierdza Kongregacja: „Nieuniknioną konsekwencją legalizacji prawnej związków homoseksualnych jest podważenie definicji małżeństwa" ${ }^{\text {"2 }}$. Wobec tego rodzaju aktów, które stają w radykalnej sprzeczności z celem małżeństwa i rodziny, Kongregacja Nauki Wiary oświadcza, iż w takim razie „państwo działa arbitralnie i wchodzi w konflikt z własnymi obowiązkami" ${ }^{43}$. Dla odparcia zaś zarzutu, że niepopieranie legalizacji rzeczonych związków stoi w sprzeczności z zasadą szacunku i niedyskryminacji wobec każdej osoby, stwierdza, powołując się na słowa św. Tomasza z Akwinu, że: „odmowa uznania prawnego czy przyznania pewnego świadczenia społecznego nie są dopuszczalne tylko wtedy, gdy pozostają w sprzeczności ze sprawiedliwością"44. Stwierdzenie to kończy się następującą, o zasadniczym znaczeniu konkluzją: „Nieprzyznanie statusu społecznego i prawnego małżeństwa formom życia, które nie są i nie mogą być małżeńskimi, nie sprzeciwia się sprawiedliwości, ale przeciwnie, jest przez nią wymagane" 45 . Nie wytrzymuje również próby zarzut łamania zasady słusznej autonomii osobistej. W odpowiedzi na tego rodzaju obiekcję Kongregacja Nauki Wiary mówi:

Inną jest rzeczą to, że pojedynczy obywatele mogą swobodnie zajmować się działalnością, dla której żywią zainteresowanie, oraz że działania te mieszczą się w powszechnym prawie cywilnym

${ }^{40}$ Tamże, 7, s. 16. Por. Deklaracja Praw Dziecka uchwalona przez Zgromadzenie Ogólne ONZ w dniu 20 listopada 1959 roku, [w:] J. Simonides, Międzynarodowa ochrona praw człowieka, Warszawa 1977, s. 347-350.

${ }^{41}$ Por. Kongregacja Nauki Wiary, Uwagi dotyczace projektów..., 8, s. 16.

${ }^{42}$ Tamże. Por. definicję małżeństwa: Sobór watykański II, Konst. Gaudium et spes, 48; KPK, kan. 1055.

${ }^{43}$ Kongregacja Nauki Wiary, Uwagi dotyczace projektów..., 8, s. 16-17.

${ }^{44}$ Tamże, 8, s. 17. Wypada przywołać tu zasadę sprawiedliwości rozdzielczej, która reguluje to, co wspólnota winna jest obywatelom proporcjonalnie do ich wkładu i ich potrzeb. Por. KKK 2411.

${ }^{45}$ Kongregacja Nauki Wiary, Uwagi dotyczące projektów..., 8, s. 17. 
do wolności; zupełnie inną rzeczą jest to, że działania, które nie wnoszą znaczącego ani pozytywnego wkładu w rozwój osoby i społeczności, miałyby otrzymywać od państwa specyficzne i określone uznanie prawne ${ }^{46}$.

Jeśli zatem małżeństwo i rodzina zasługują, ze względu na pozytywny wkład w rozwój osoby i społeczności, na właściwe i specyficzne uznanie prawne, to związki homoseksualne, e contrario, ze względu na ich szkodliwe działanie, na nie nie zasługują ${ }^{47}$.

Argumenty przemawiające za porządkiem prawnym społeczności

przeciw legalizacji związków homoseksualnych

Porządek prawny danej społeczności - rzecz jasna - nie stanowi per se celu samego w sobie. Niemniej jest on istotnym warunkiem i podstawą dla właściwego jej funkcjonowania i realizacji wielorakich zadań, co w rezultacie służy jej rozwojowi. Siłą motoryczną, która leży u podstaw ładu i porządku społecznego, są zatem zasady prawego rozumu (recta ratio), o których była mowa wyżej. Tylko w tak rozumianym porządku społecznym znajduje się odpowiednie miejsce dla pierwszych i naturalnych społeczności, jakimi są małżeństwo, rodzina oraz pochodny od niej naród, wreszcie cały rodzaj ludzki ${ }^{48}$.

Prawdę na temat doskonałej w swym ontologicznym wyrazie struktury małżeństwa i odpowiadającej jej, zgodnie z Boskim postanowieniem rodziny, dzięki którym od zarania ludzkości realizuje się jej główny i doniosły cel, musi budzić w każdym zdrowo uformowanym człowieku oraz w ogólnym odczuciu zdumienie, podziw i uczucie wdzięczności wobec zamysłu mądrości i dobroci Stwórcy. Czyż nie wyrażają tego pierwsze w tej kwestii słowa Księgi Rodzaju ${ }^{49}$. Czyż można wyrazić głębiej i w sposób bardziej fascynujący słowa przesłania Stwórcy do swego stworzenia: „Bądźcie płodni i rozmnażajcie się, abyście zaludnili ziemię" $(\operatorname{Rdz} 1,28)$. Odnosząc się do tych słów, wyznaczających, najogólniej rzecz biorąc, egzystencjalny program mężczyzny i kobiety w ich prawowitym związku małżeńskim, Nauczycielski Urząd Kościoła wyjaśnia i wskazuje: „Mężczyzna i kobieta, stworzeni na obraz Stwórcy, który miłuje «wszystkie stworzenia» (Mdr 11, 24), są powołani, by uczestniczyć w Opatrzności Bożej w stosunku do innych stworzeń. $Z$ tego wynika ich odpowiedzialność za świat powierzony im przez Boga" ${ }^{50}$. W konsekwencji tak rozumianego związku, jak stwierdza tekst Kongregacji:

46 Tamże, 8, s. 17-18.

${ }^{47}$ Por. tamże.

${ }^{48}$ Naturalne tendencje wspólnototwórcze, którymi charakteryzują się wspomniane społeczności, a także ontologiczno-socjologiczny związek między nimi, stanowią istotny argument za zachowaniem porządku i ładu, służącemu ich prawidłowemu rozwojowi. Por. Międzynarodowa Komisja Teologiczna, $W$ poszukiwaniu etyki uniwersalnej. Nowe spojrzenie na prawo naturalne, tłum. R. Kiełtyka, Kraków 2010, s. 77-87.

${ }^{49}$ Por. Rdz 2, 7. 22; KKK 369.

${ }^{50}$ KKK 373; Sobór watykański II, Konst. Gaudium et spes, 50; Jan Paweł II, Adh. Familiaris consortio, 28. 
„Jako że pary małżeńskie mają za zadanie zagwarantowanie następstwa pokoleń, a zatem wyraźnie przyczyniają się do dobra publicznego, prawo nadaje im znaczenie instytucjonalne" 51 . W sytuacji diametralnie przeciwnej plasują się związki homoseksualne. Dlatego w myśl nauki Magisterium Kościoła: „Związki homoseksualne [...] nie wymagają szczególnej uwagi ze strony ustawodawstwa prawnego, ponieważ nie odgrywają wspomnianej roli dla dobra wspólnego" ${ }^{2}$.

Natomiast w odpowiedzi na wysuwane argumenty, według których zalegalizowanie prawne związków homoseksualnych jest rzekomo konieczne dla zapobieżenia sytuacji, w której współżyjący homoseksualiści straciliby, ze względu na sam fakt ich współżycia, rzeczywiste uznanie ich powszechnych praw, które mają jako osoby i jako obywatele, Kongregacja odpowiada: „W rzeczywistości mogą oni zawsze odwołać się - jak wszyscy obywatele, na podstawie swej prywatnej autonomii - do powszechnego prawa do ochrony sytuacji prawnych wspólnego interesu" 53 .

Powyższe uwagi Kongregacji kończy następujący wniosek, który jest prostą wypadkową refleksji w tej niezwykle newralgicznej sprawie: „Stanowiłoby natomiast poważną niesprawiedliwość poświęcenie dobra wspólnego i słusznego prawa rodziny, w celu uzyskania dóbr, które mogą i muszą być gwarantowane w sposób nieszkodzący całemu organizmowi społecznemu" 54 .

$*$

Powyższe refleksje i uwagi, jak zostało we wstępie zaznaczone, mają jedynie przybliżyć racjonalność użytych argumentów przez Magisterium Kościoła na rzecz słusznych rozwiązań nauki, określeń i ustaleń prawnych dla promocji małżeństwa i rodziny, jako jedynych form zdrowej gwarancji rozwoju poszczególnych osób oraz społeczności ludzkich.

Tekst zakończenia dokumentu Kongregacji Nauki Wiary stanowi znakomitą rekapitulację argumentów, na kanwie których wykazano, iż nic nie usprawiedliwia aktów sankcjonowania związków homoseksualnych. Tego rodzaju akty legalizacji są ostatecznie swoistym zamachem na małżeństwo i rodzinę, które opierają się na podstawowych wartościach, należących do wspólnego dziedzictwa ludzkości. Dlatego też, jak czytamy w ostatnim zdaniu dokumentu: „Kościół nie może nie bronić tych wartości ze względu na dobro ludzi i całej społeczności"s5.

W kontekście poczynionych rozważań przypomina się naglące pytanie Jana Pawła II, któremu nie można odmówić roli autorytetu wielkiego świadka nowożytnych czasów. Papież zaś kierował te pytania nie tylko do współczesnych:

\footnotetext{
${ }^{51}$ Kongregacja Nauki Wiary, Uwagi dotyczace projektów..., 9, s. 18.

${ }^{52}$ Tamże.

${ }^{53}$ Tamże, 9, s. 18-19.

${ }^{54}$ Tamże, 9, s. 19.
}

${ }^{55}$ Tamże, 11, s. 22; Por. Pontificio Consilio per la Famiglia, Familia, matrimonio e , unioni di fatto”, [w:] Enchiridion Vaticanum. Documenti ufficiali della Santa Sede, Bologna 2000, 19/1103-1117; G. Marcel, Mądrość i poczucie sacrum..., s. 41-74. 
Dlaczego się to wszystko dzieje? Jaki jest korzeń tych ideologii pooświeceniowych? Odpowiedź jest - jak sam mówi - jednoznaczna i prosta: dzieje się to po prostu dlatego, że odrzucono Boga jako Stwórcę, a przez to jako źródło stanowienia o tym, co dobre, a co złe. Odrzucono to, co najgłębiej stanowi o człowieczeństwie, czyli pojęcie „natury ludzkiej” jako „rzeczywistości”, zastępując ją ,wytworem myślenia” dowolnie kształtowanym i dowolnie zmienianym według okoliczności ${ }^{56}$.

Papieskie słowa nie wymagają tu komentarza, stanowią jednak rodzaj przestrogi: człowiek nie może być przedmiotem eksperymentu.

\section{Summary}

\section{Irrationality of legalization of homosexual partnerships vis-à-vis theunique and irreplaceable value and role of marriage and family}

The problem treated in the paper refers to acts of legalization of homosexual partnerships which meets strong opposition not only from the Church but also from all the people who believe that marriage and family, rooted in the natural divine law, assure a proper development of these institutions while constituting the guarantee of the development of individual persons and societies.

A common sense rational argument (recta ratio) in favor of respect for natural law, verified in the entire experience of human society by the existence of marriage and family, does not agree with acts of authorizing and legitimizing partnership of persons of the same sex.

Rejection of - as John Paul II said - God as the Creator, and thus the rejection of the source of determining that which is good and wrong, stands as the root cause of the contestation of the notion of the "human nature". Therein lies the essence of the problem of evil. There is then a justified hope that the acts in question will be disapproved and rejected by all who follow rational argument (recta ratio).

\section{Keywords}

Catholic Church, family, homosexual partnership, marriage, John Paul II, society

\footnotetext{
${ }^{56}$ Jan Paweł II, Pamięć i tożsamość, s. 20.
} 